\title{
STUDY ON PHYSICAL-CHEMICAL PROPERTIES OF FURNACE-NICKEL-SLAG POWDER FOR GEOPOLYMER APPLICATION
}

\author{
S. Samnur ${ }^{1}$, H. Husain ${ }^{2}$, A. Zulfi², E. H. Sujiono ${ }^{2 *}$ \\ ${ }^{1}$ Department of Mechanical Engineering, Faculty of Engineering, Universitas Negeri Makassar, Indonesia \\ ${ }^{2}$ Department of Physics, Faculty of Mathematics and Sciences \\ Universitas Negeri Makassar, Indonesia
}

Received: 13 April 2016. Accepted: 28 May 2016. Published: July 2016

\begin{abstract}
This research aims to prepare powder of nickel slag from furnace machine, identify, and analyze of the elements or compounds containing in the sample. The data retrieval was done with the analysis of elemental composition, phase microstructures, crystal size, distribution, and composition mapping of the samples by using XRD, Rigaku Miniflex II, and SEM-EDS, Tescan Vega-3. XRD result indicates that the formation which the similar to amorphous phase was identified and the formation at peak $2 \theta=28.01^{\circ}$ is identified as the low quartz $\left(\mathrm{SiO}_{2}\right)$. FWHM $0.18^{\circ}$ was obtained using microcal origin 6.0 and average crystal size $53.37 \mathrm{~nm}$ was obtained by applying Scherer equation. SEM results show average grain size of samples which is less than $1 \mu \mathrm{m}$ and maximum to $4 \mu \mathrm{m}$. Based on EDS result, the main constituent elements are Si $32.86 \mathrm{wt} \%, \mathrm{Mg} 19.40$ wt $\%$, and $\mathrm{Fe} 32.03 \mathrm{wt} \%$, respectively.
\end{abstract}

\begin{abstract}
ABSTRAK
Penelitian ini bertujuan untuk menyiapkan bubuk slag nikel yang berasal dari furnace, yang dilanjutkan dengan mengidentifikasi dan menganalisis unsur atau paduan yang terkandung di dalamnya. Data diperoleh dengan melakukan analisis terhadap komposisi unsur, fasa mikrostruktur, ukuran Kristal, distribusi dan komposisi paduan dari sampel bubuk slag nikel furnace dengan menggunakan XRD tipe Rigaku Miniflex II dan SEM-EDS tipe Tescan Vega-3. Hasil analisis XRD menunjukkan bahwa formasi yang dihasilkan menyerupai fase amorf dan formasi yang terbentuk pada puncak $2 \theta=28.01^{\circ}$ diidentifikasi sebagai low quartz $\left(\mathrm{SiO}_{2}\right)$. Dengan menggunakan microcal origin 6.0 diperoleh FWHM $0.18{ }^{\circ}$ dan menggunakan persamaan Scherer diperoleh rata-rata ukuran kristal $53.37 \mathrm{~nm}$. Hasil pengukuan SEM menunjukkan bahwa rata-rata ukuran butir dari sampel bubuk slag nikel furnace bervariasi antara minimal $1 \mu \mathrm{m}$ dan maksimum $4 \mu \mathrm{m}$. Berdasarkan pengukuran EDS diperoleh secara berturut-turut bahwa unsur utama penyusun paduan slag nikel furnace adalah Si 32.86 wt\%, Mg 19.40 wt\%, dan Fe 32.03 wt\%.
\end{abstract}

(C) 2016 Jurusan Fisika FMIPA UNNES Semarang

Keywords: chemical composition; grain size; nickel slag; physical-chemical properties; powder

\section{INTRODUCTION}

Many studies conducted a nickel slag utilization, some of them were in the field of construction at many countries, as considering the nickel slag production can reach thousands of ton every week (Prederiy, 2011; Huang, Bird, Heidrich, 2007; and Motz \& Geizeler, 2010). Addition, at the developing countries, nickel slag

${ }^{*}$ Correspondence Address:

Kampus UNM Parangtambung 90224

E-mail: e.h.sujiono@unm.ac.id is utilized in the construction of highways such as for granular and hot-mix asphalt aggregate (engineered fill, sub base and base material, and asphalt concrete), aggregate of concrete manufacturing (fine and coarse aggregate) and cementations application (blended cement and raw material for cement manufacture) (Wang \& Thompson, 2011). Nickel slag also used in industrial blast cleaning as ultra blast with a high density disposable blasting slag which has several advantages such as high production rates, non-reactant, and non-detectable 
crystalline. Utilization of nickel slag depends on its mechanical properties, electrical properties and morphology, which are largely affected by the physical-chemical composition and crystal structure (Zhang \& Chou, 2012; and Ghosh, Krishnamuthy, Sankaranayanan, 2010). Information of the physical-chemical composition and crystal structure of nickel slag become very important to determine its future material applications.

In this paper, the samples of nickel slag powder come from the smelting process of nickel ore after furnace processing. The analysis was focused on the physical-chemical properties of materials based on the characterization data by using X-ray Diffraction (XRD), Scanning Electron Microscopy (SEM) and Energy Dispersive Spectroscopy (EDS).

\section{METHOD}

The procedure in this research is started from sample preparation of furnace nickel slag in solid form that processed into a powder, followed by analysis of micro structures through characterization by XRD and SEM and mineral composition analysis using EDS.

\section{Sample Preparation}

Hard chunks of furnace nickel slag, caused the process of nickel slag into a fine aggregate without using a machine becomes very difficult. Furnace nickel slag procedures into powder form begin with destruction to gravel size by using Jaw Crusher W 200 machine. Slag size gravel is rinsed with water to minimize contamination, and then dried in a furnace at temperature $170{ }^{\circ} \mathrm{C}$ for 30 minutes. The slag is dried then crushed using a Jaw Crusher W 200 to produce nickel slag sand. Slag which is processed by Jaw Crusher W 200, then processed again by milling, PAL-M100M, and resulted smooth output. The obtained sample from the processing chunk of nickel slag is formed at the laboratory of Material Sciences, Department of Physics, Universitas Negeri Makassar which is shown in Figure 1.

\section{Microstructure Analysis}

Information of the microstructure sample gathered through the XRD and SEM data analysis. Microstructure properties of materials obtained from XRD such as crystal ability of material, the average of crystal size, and full width half maximum (FWHM), can determine the electrical properties and crystal quality of ma- terials (Wickenden \& Kisthemnacer, 1994; and Sujiono, Sani, Saragi, Arifin, Barmawi, 2001). On the other hands, the grain size and patterns of particle distribution are factor that can determine the mechanical properties of the materials. This data obtained from SEM analysis.

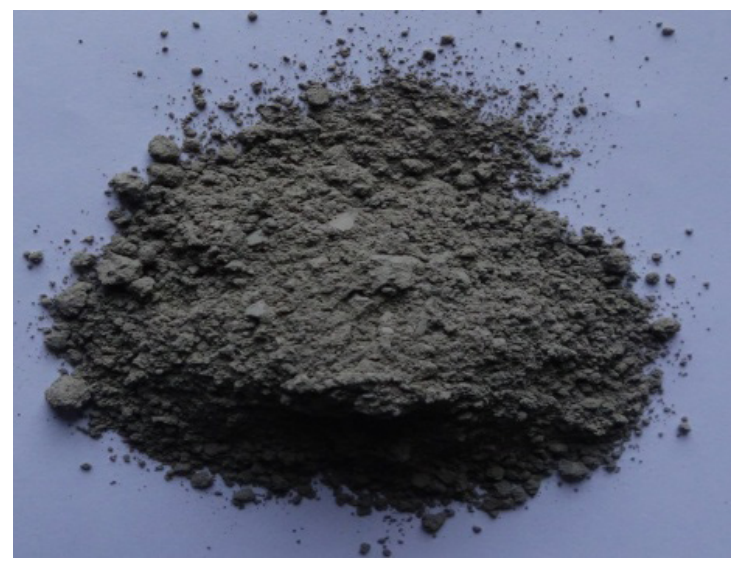

Figure 1. Sample of furnace nickel slag powder.

\section{Mineral Composition}

Analysis of EDS data results was used to determine the element of nickel slag samples. This result can be used to identify the dominant constituent element of materials. This data is very important as the basis of utilization of the materials based on the characteristics of the element constituting, and the basic separation of nickel slag elements by using the appropriate method such as reduction under vacuum condition (Deng, Liu, Yao, Ma, 2014). Average particle size can be calculated from the top of the highest intensity by using the Debye-Scherer:

$\mathrm{t}=\mathrm{k} \lambda / \mathrm{B} \cos \theta$

where, $\mathrm{t}$ is the average of crystal size, $\mathrm{k}$ is the Scherer constant (0.89), $\lambda$ is the wavelength of the X-rays, $B$ is the FWHM in radiant, and $\theta$ is the angle of Bragg's diffraction, respectively (Khalil, Saad, Wahsa., 2012; and Kumar, Kumar, Narayan, Manoranjan, 2013).

\section{RESULT AND DISCUSSION}

\section{Characteristics of Furnace Nickel Slag Pow- der}

Based on the aggregated sample size of the nickel slag is in the range of $0-30 \mathrm{~mm}$, so that the its advantages are wider. For instance, the slag with a grain size between $9.5-4.75$ $\mathrm{mm}$ can be used as coarse aggregate and slag with a grain size between $4.75-0.075 \mathrm{~mm}$ can 
be served as a fine aggregate such as in application for prestressed concrete, concrete block, etc. (ASA, 2011). While the nickel slag in powder provides wide opportunities of utilize the nickel furnace slag and further research on mixing the powdered sample with other powder materials to improve the quality of materials in order to maximize its application.

\section{Physical Properties}

Analysis of SEM result was used to analyze the surface morphology, size, and form of granules, pattern of granules distribution, mapping elements and compounds of nickel slag furnace constituents. Figure 2.a shows the result of SEM characterization of nickel slag furnace with 81 times magnification, using an SE detector at $15 \mathrm{kV}$. The grain size of nickel slag has a size of more than $1500 \mu \mathrm{m}$, the brightwhite dots on the surface of grain are $\mathrm{Ti}$ at $0.20 \%$ and constituent element was taken with the highest atomic number that has the highest level of brightness.

Figure 2.b shows the result of SEM characterization of nickel slag powder furnace with 2000 times magnification. A grain of nickel slag has various size, $1 \mu \mathrm{m}-4 \mu \mathrm{m}$. It can provide a wide option for processing nickel slag furnace in micro scale particles. The EDS data indicates that the main elements of a sample are $\mathrm{Si}$ and $\mathrm{Fe}$. The Si rich area on the SEM image (Figure 2.b) is marked with "B" on darker part, whereas the Fe rich area is marked with " $A$ " on the brighter part because $\mathrm{Fe}$ has a higher atomic number than $\mathrm{Si}$. It is so because the smaller of their atomic number leads to the less reflection appears as a darker area on the image of SEM characterization.

Figure 2.c showed nickel slag furnace powders with 5000 times magnification, while the scale of $5 \mu \mathrm{m}$ is focused on the Fe. The Fe grain size is various, where some discharge electron can be seen at Fe granules because of its position, on the grain boundary.
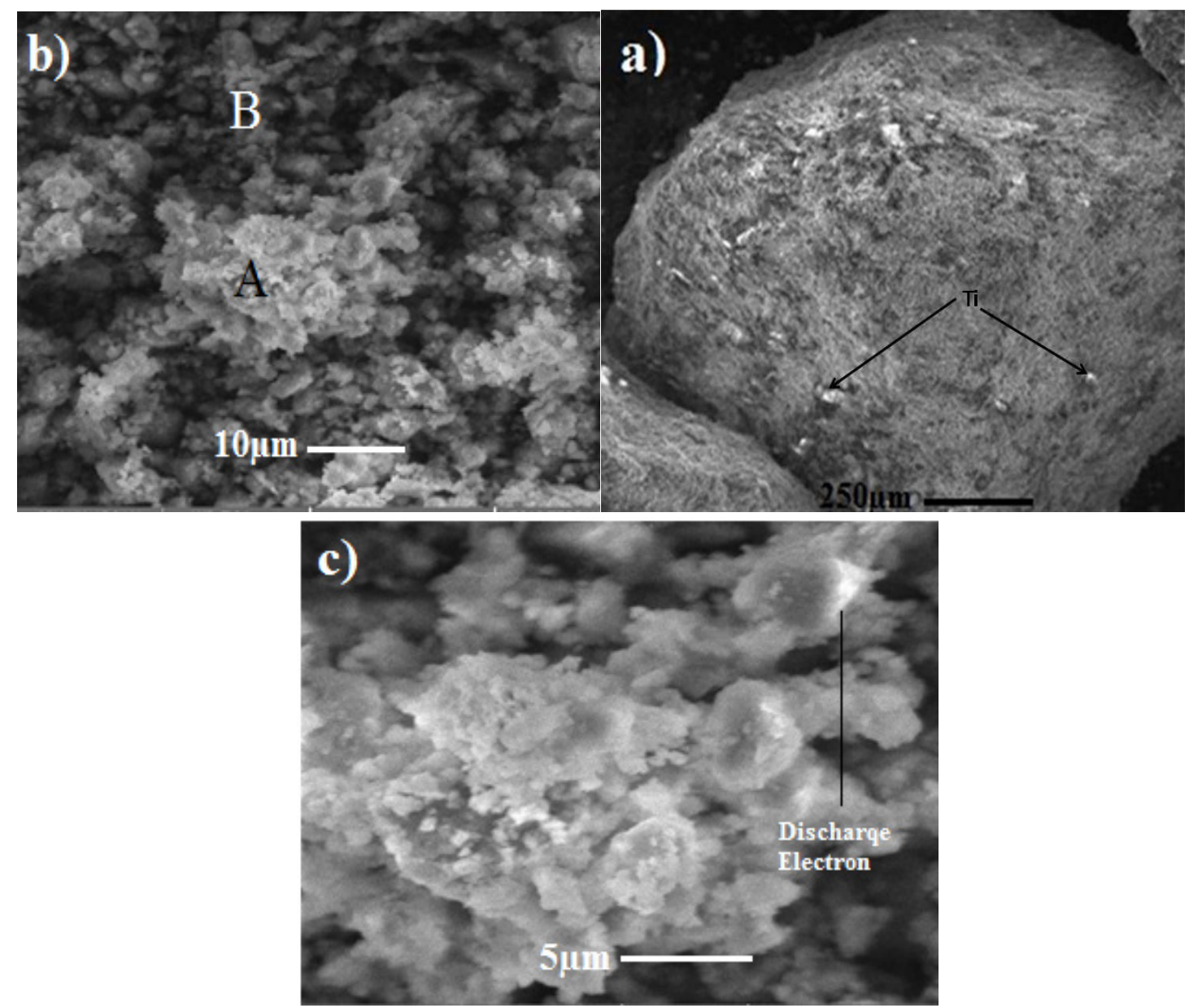

Figure 2. SEM image of: a) Nickel slag furnace with 81 times magnification (Ti appears as bright dots). b) Nickel slag furnace with 2000 times magnification ( $A=F e$ rich area; $B=$ Si rich Area). c) Nickel slag furnace with 5000 times magnification. 


\section{Chemical properties}

The XRD data shows the compounds with its crystal phase are indicated by the presence of sharp peaks while the other phase resemble the amorphous phase that is indicated by the formation of the hump with an irregular intensity, revealing a characteristic for sample is in powder form.

XRD pattern in Figure 3 shows the patterns of nickel slag powder with some emergence of the crystal phase and amorphous like phase of nickel slag. Data retrieval at the angle of $2 \theta$ starts from $20^{\circ}-80^{\circ}$ with $\lambda=1.54 \mathrm{~nm}$ at 30 $\mathrm{kV}$ and $15 \mathrm{~mA}$.

The most dominant peak is on (113) field with the intensity of the 1866 counts at the angle of $2 \theta$ is $28.01^{\circ}$. The field shows the phase hypothetical silica $\left(\mathrm{SiO}_{2}\right)$ with $32.86 \mathrm{wt} \%$ is similar with the dominant mineral in powder furnace nickel slag from literature (Pan et al., 2013) but this sample has a larger $\mathrm{FeO}$, so its possible to make a new alloy material rich with $\mathrm{FeO}$ by adding powder nickel slag as an aggregate. FWHM value obtained from the Microcal Origin 6.0 was $0.18^{\circ}$, this value is quite small refer to literature, that mean this phase has a good crystal structure and electrical properties (Wickenden and Kisthemnacer, 1994; and
Sujiono et al., 2001) and by Scherer equation acquired crystal size of $53.37 \mathrm{~nm}$. Next on the field of (221) and intensity of the 482 counts at an angle of $2 \theta 29.69^{\circ}$ and in field (310) with the intensity of 1470 counts at an angle $2 \theta$ is $30.99^{\circ}$ show the clinoenstatite $\left(\mathrm{Mg}\left(\mathrm{SiO}_{3}\right)\right)$ phase. In the field of (122) and the intensity of the 178 counts at an angle $2 \theta$ of $42.36^{\circ}$ shows the phases of silimanite $\mathrm{Al}_{2}\left(\mathrm{SiO}_{4}\right) \mathrm{O}$. In the field of (110) and the intensity of 1169 counts at an angle of $2 \theta 36.36^{\circ}$ shows the phases of magnetite $\left(\mathrm{Fe}_{2} \mathrm{O}_{3}\right)$. Whereas in the field of (200) and the intensity of the 849 counts at an angle of $2 \theta$ is $35.58^{\circ}$ shows the phases of calcium peroxide $\left(\mathrm{CaO}_{2}\right)$. The formation of both clinoenstatite $\left(\mathrm{Mg}\left(\mathrm{SiO}_{3}\right)\right)$ and silimanite $\mathrm{Al}_{2}\left(\mathrm{SiO}_{4}\right) \mathrm{O}$ phase show that Si can bound with $\mathrm{Mg}$ and Al. The absence of compound between $\mathrm{Si}$ and $\mathrm{Fe}$ or $\mathrm{Ca}$ indicated that these elements cannot bound together or the diffraction is quite small to detect by XRD detector.

Chemical composition of powder furnace nickel slag from XRD analysis as shown in Figure 4 shows that the highest phase is clinoenstatite $68 \%$. In addition there is another compound like hypothetical silica $13 \%$, iron (III) oxide $12 \%$, silimanite $4 \%$ and calcium peroxide $3 \%$.

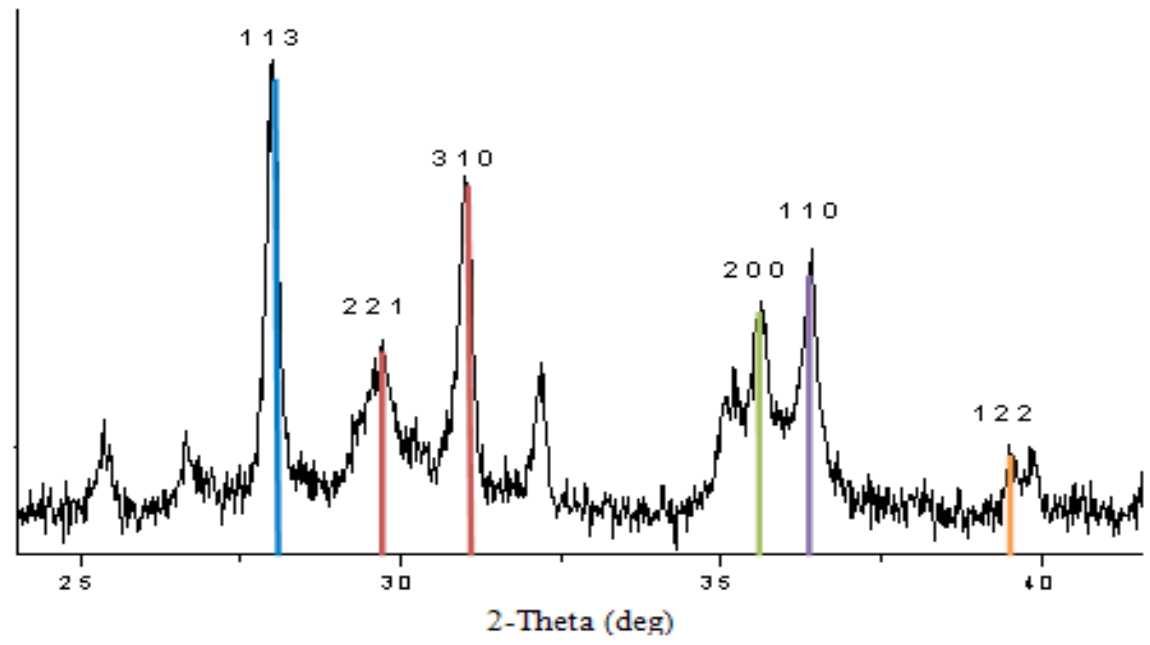

hypothetikal silica $\left(\mathrm{SiO}_{2}\right)$

Clinoenstatite $\left(\mathrm{Mg}\left(\mathrm{SiO}_{3}\right)\right)$

Silimanite $\mathrm{Al}_{2}\left(\mathrm{SiO}_{4}\right) \mathrm{O}$

hematite HP, iron(III) oxide

Calcium Peroxide $\left(\mathrm{Ca} \mathrm{O}_{2}\right)$

Figure 3. XRD pattern of powder furnace nickel slag. 
Table 1. The EDS data of furnace nickel slag powder.

\begin{tabular}{llllllllllll}
\hline Symbol & $\mathrm{Si}$ & $\mathrm{Al}$ & $\mathrm{Na}$ & $\mathrm{Fe}$ & $\mathrm{Mn}$ & $\mathrm{Cr}$ & $\mathrm{Ca}$ & $\mathrm{Mg}$ & $\mathrm{S}$ & $\mathrm{Ti}$ & $\mathrm{Co}$ \\
\hline Percentage [\%] & 32.86 & 4.02 & 0.25 & 32.03 & 0.50 & 2.07 & 7.82 & 19.40 & 0.24 & 0.20 & 0.60 \\
\hline
\end{tabular}

\section{Chemical Composition}

The EDS result provides information on the chemical composition of furnace nickel slag as shown in the Table 1. There are three dominant elements $\mathrm{Si}, \mathrm{Fe}$, and $\mathrm{Mg}$. These elements could be extracted from powder furnace nickel slag for further application, such as to extract $\mathrm{Mg}$ using carbonation process (Wen-ning, Yuchun \& Yan, 2010) and to extract Fe element with precipitation method.

Furthermore, the presence of $\mathrm{Si}$ and $\mathrm{A}$ with ratio larger than 8 in powder furnace nickel slag give a possibility to use it as a raw material in synthesis geopolymer (Davidovits, 1994; Rangan, 2010), which has chain structure from $\mathrm{Si}$ and $\mathrm{Al}$ ions (Cheng \& Chiu, 2003; Maragkos, Giannopoulou \& Panias, 2009). Based on these results of the compounds contained in samples of powdered, furnace nickel slag can be separated using physical chemical methods whose results are expected to support the acceleration of the Indonesia economic development master plan.

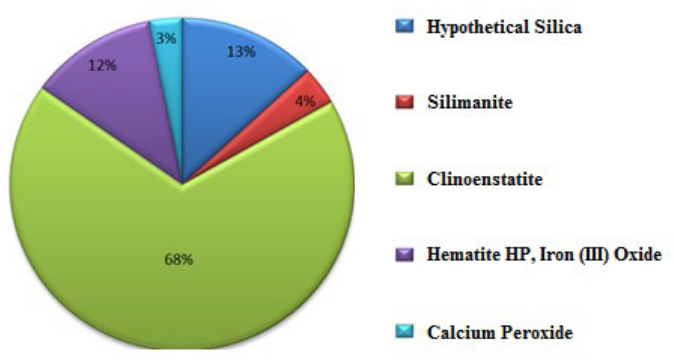

Figure 4. Percentage of compound in powder furnace nickel slag sample

\section{CONCLUSION}

Sample powder of furnace nickel slag with varied grain size on the first stage has successfully produced. SEM measurement data analysis result shows grain size for sample furnace slag powder on average $1 \mu \mathrm{m}-4$ $\mu \mathrm{m}$. XRD data analysis indicated resemble an amorphous phase formation was characterized by the presence of hump, with its highest peak at $2 \theta=28.01^{\circ}$ which is a phase of low quartz $\left(\mathrm{SiO}_{2}\right)$, with the average FWHM of 0.18 and crystal size $53.37 \mathrm{~nm}$. The analysis of EDS indicates that major elements of nickel furnace slag powder are Si $32.86 \%$ wt, Mg $19.40 \%$ wt and $\mathrm{Fe} 32.03 \% \mathrm{wt}$, respectively. The presence of $\mathrm{Si}$ and $\mathrm{Al}$ element with ratio larger than 8 is possible to use as a raw material for synthesis of a geopolymer.

\section{ACKNOWLEDGEMENT}

This research was funded by the Directorate General Of Higher Education, Ministry of Education and Cultural Indonesia through Priority Research Scheme "MP3El" fiscal year 2013 no. contract: 284/SP2H/PL/Litabmas/ VII/ 2013, 15 July 2013, and this article has been presented in International Conference on Functional Materials and Metallurgy 2014 (ICoFM 2014) on $17^{\text {th }}-18^{\text {th }}$ September 2014 in Penang, Malaysia.

\section{REFERENCES}

ASA. (2011). Blast Furnace Slag Aggregates Properties, Characteristics and Applications, Retrieved from http://www.asa-inc.org.au/documents/ASA-ReferenceDataSheet-2.pdf.

Cheng, T. W., \& Chiu, J. P. (2003). Fire-resistant geopolymer produced by granulated blast furnace slag. Minerals Engineering, 16(3), 205-210.

Davidovits, J. (1994). High-Alkali Cements for $21^{\text {st }}$ Century Concretes. Proceedings of V. Mohan Malhotra Symposium, Editor: P. Kumar Metha, ACl SP- 144 (pp. 383-397). Berkeley:,Ucla.

Deng, P., Liu, Y., Yao, W., Ma, H. (2014). Production of Primary Magnesium by the Aluminothermic Reduction of Magnesia Extracted from Dolomite Ore. J. Material Science Forum, 788, 28-33.

Ghosh, D., Krishnamuthy, V.A., Sankaranayanan, S.R. (2010). Application of Optical Basicity to Viscosity of High Alumina Blast Furnace Slags, Min.Metall. Sect. B-Metall, 46(1), 4149.

Huang, Y., Bird, R. N., \& Heidrich, O. (2007). A review of the use of recycled solid waste materials in asphalt pavements. Resources, Conservation and Recycling, 52(1), 58-73.

Khalil, M.N., Saad, E.E., Wahsa (2012). "Extraction Nanosized $\mathrm{a}-\mathrm{Fe}_{2} \mathrm{O}_{3}$ Particles From Hematite Ore" Proceeding of the 3rd International Conference on Chemistry and Chemical Engineering(pp. 82-87). Singapore: IPCBEE. Kumar, L., Kumar, P., Narayan, A., \& Kar, M. (2013). 
Rietveld analysis of XRD patterns of different sizes of nanocrystalline cobalt ferrite. International Nano Letters, 3(1), 1-12.

Maragkos, I., Giannopoulou, I. P., \& Panias, D. (2009). Synthesis of ferronickel slag-based geopolymers. Minerals Engineering, 22(2), 196-203.

Motz, H., Geizeler, J. (2010). Products of Steel Slag an Opportunity to Save Natural Resources, J. Waste Management, 21(3), 285-293.

Mu, W. N., Zhai, Y. C., \& Yan, L. I. U. (2010). Leaching of magnesium from desiliconization slag of nickel laterite ores by carbonation process. Transactions of Nonferrous Metals Society of China, 20, 87-91.

Optaminerals (n.d.). Ultrablast - Nickel Slag. Retrieved from: http://www.optaminerals.com/ abbrasives/Ultrablast-Nickel-Slag.html

Pan, C., Lv, X., Bai, C., Liu, X., \& Li, D. (2013). Melting features and viscosity of $\mathrm{SiO} 2-\mathrm{CaO}-\mathrm{MgO}$ $\mathrm{Al} 2 \mathrm{O} 3-\mathrm{FeO}$ nickel slag in laterite metallurgy. Journal of Mining and Metallurgy B: Metallurgy, 49(1), 9-12.

Prederiy, I. (2011). Dissolution of Valuable Metals from Nickel Smelter Slags by Means of High
Pressure Oxidative Acid Leaching, Canada: University of Toronto.

Rangan, B. V. (2010). Fly Ash-Based Geopolymer Concrete.Proceedings of the International Workshop on Geopolymer Cement and Concrete, (pp. 68-106). Mumbai: Allied Publishers Private Limited.

Sujiono, E.H., Sani, R.A., Saragi, T., Arifin, P., Barmawi, M. (2001). $\mathrm{YBa}_{2} \mathrm{Cu}_{3} \mathrm{O}_{7-\delta}$ Thin Films Deposited by MOCVD Vertical Reactor with a Flow Guide, Physica Status Solidi (a)., 187(2), 471-479.

Wang, G., Thompson, R. (2011). Slag Use in Highway Construction-the Phylosophy and Technology of Its Utilization, International Journal of Pavement Research and Technology, 4(2), 97-103.

Wickenden, A.E, Kisthemnacer, D.K. (1994). The Effect of Thermal Annealing on GaN Nucleation Layers Deposited on (0001) Shapphire by Metalorganic and Chemical Vapor Deposition, Apply. Physc, 75(10), 5367-5371.

Zhang, G.H., Chou, K.C. (2012). Viscosity Model for Fully Liquid Silicate Melt, Min. Metall. Sect. B-Metall, 48(1)B 1-10. 